Universität
Basel

Wakultät

October 2015

\title{
What Drives Public Health Care Expenditure Growth? Evidence from Swiss Cantons, 1970-2012
}

Universität Basel

Peter Merian-Weg 6

4052 Basel, Switzerland

wwz.unibas.ch
Corresponding Author:

Thomas Braendle

Tel: +41 (0) 584623992

Mail: thomas.braendle@efv.admin.ch 


\title{
What Drives Public Health Care Expenditure Growth? Evidence from Swiss Cantons, 1970-2012*
}

\author{
Thomas Braendle ${ }^{\dagger}$ and Carsten Colombier ${ }^{\ddagger}$
}

October 5, 2015

\begin{abstract}
A better understanding of the determinants of public health care expenditures is key to designing effective health policies. We integrate supply and demand-side determinants, factors from political economy and health policy reforms into an empirical analysis of the highly decentralized Swiss health care system. We compile a novel data set of the cantonal health care expenditure in Switzerland spanning the period 1970 - 2012. Using dynamic panel estimation methods, we find that per capita income, the unemployment rate and the share of foreigners are positively related to public health care expenditure growth. With regard to political economy aspects, public health care expenditures increase with the share of women elected to parliament. However, institutional restrictions for politicians, such as fiscal rules and mandatory fiscal referenda, do not appear to limit public health care expenditure growth.
\end{abstract}

Keywords: Public health care expenditure, Panel data, Fiscal rules, Political selection

JEL classification: H75, D72, C23, I18

${ }^{*}$ We thank Martin Baur, Pierre-Alain Bruchez, Sandra Daguet, Serge Gaillard, Jochen Hartwig, Margit Himmel, Fabienne Marti Locher, Christian Müller, Arabela Philipona, Reo Tataku, Marcel Widmer, Philippe Widmer, participants at the Economics Research Seminar at the Free University of Bolzano, the Economics Research Seminar at the University of Fribourg, the Annual Meeting of the International Health Economics Association at Bocconi, Milan, the Annual Meeting of the IIPF in Dublin, the International Conference on Health, Economics and Management, Augsburg, the OECD Network Meeting on Fiscal Sustainability of Healthcare Systems in Paris, the Federal Finance Administration Brown Bag Seminar in Berne, and the participants of the Dreiländertreffen of the Ministries of Finance in Berlin for helpful comments. We are grateful to Alois Stutzer and Patricia Funk for providing data on Swiss political institutions. This paper expresses the opinion of the authors. The paper is also published as working paper of the Federal Finance Administration and as FiFo-working paper.

${ }^{\dagger}$ Swiss Federal Department of Finance, Federal Finance Administration and University of Basel, Faculty of Business and Economics. Bundesgasse 3, 3003 Berne, Switzerland. Email: thomas.braendle@efv.admin.ch. Phone: +41 584623992.

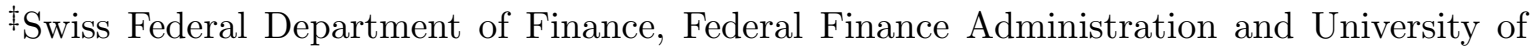
Cologne, FiFo-Institute for Public Economics. Bundesgasse 3, 3003 Berne, Switzerland. Email: carsten.colombier@efv.admin.ch. Phone: +41584626332. 


\section{Introduction}

An ever increasing share of national income is spent on health care. This development puts continuous pressure on public budgets and poses a major challenge for economic policy makers. So far, an overwhelming majority of the literature has focused on supply and demand-side explanations for the growth of health care expenditure, such as the ageing of the population, increases in income as well as technological progress.

In this paper, we jointly investigate demand and supply side determinants, factors identified to be of importance by the political economy literature and health policy reforms. We exploit the highly decentralized health care system of Switzerland and focus on cantonal health care expenditure over a period of more than 40 years (1970-2012). ${ }^{1}$ The newly compiled data set is analyzed with the help of dynamic panel data estimation methods.

We study public health care expenditure in Swiss cantons for mainly three reasons. First, cantons finance about two thirds of total public health care expenditure and play a key regulatory role. Second, due to the large cantonal autonomy in designing health care policies, public health care expenditure per capita varies enormously among cantons and across time. As illustrated in Figure 1, the canton of Basle-City spends about six times more than the canton of Zug and almost two times more than the canton of Geneva in 2012, i.e., 4722 Swiss francs compared to 768 and 2778 Swiss francs per capita. Health care expenditure has developed very differently in these cantons over the last 40 years. Third, the dynamics of cantonal health care have contributed to growing concerns regarding fiscal sustainability. Accordingly, there is a heated debate on how to use public funds for health care in a more efficient and cost-containing way, in particular, as to how cantonal hospitals should be organized and financed.

[Figure 1 about here]

In a first step, the paper builds upon the findings in the literature. On the demand side, the income elasticity of public health care provision is studied. Unemployment is included as the probability of illness is higher for the unemployed (on the micro-level) and because it is an important indicator of the prevailing macroeconomic conditions. Furthermore, the demographic structure as to age and immigration is taken into account. While an ageing society is expected to increase public health care expenditure, the effect that immigration has is less clear. On the one

\footnotetext{
${ }^{1}$ While experts attest the high quality of health care services, the Swiss health care system is one of the most expensive systems in the OECD. Total health care expenditure as a percentage of GDP has more than doubled since 1970 and amounts to $10.9 \%$ in 2012. Long-term projections by the Swiss Ministry of Finance suggest that health care expenditure will be in the range of roughly $14 \%$ to $17 \%$ of GDP in 2060 (Colombier 2012).
} 
hand, the immigrants' demand for public health care provision might be systematically higher due to different preferences, a different socio-economic background and the fact that immigrants have been more likely to work in riskier and physically more demanding jobs in Switzerland. ${ }^{2}$ On the other hand, immigrants are typically younger and healthier and therefore less likely to use health care services than natives. ${ }^{3}$ In addition, we try to empirically capture technological progress.

Political economists have studied the influence of political determinants on social expenditure in general. However, the literature has not yet paid much scholarly attention to the political economy of public health care expenditure. ${ }^{4}$ Therefore, in a second step, we investigate the influence that political economy determinants may have on public health care expenditure. First, following the fiscal commons problem as a prominent explanation for excessive spending, we test whether the size of parliament, as a proxy for the common pool problem with the cantonal (health) budget, increases public health care expenditure. ${ }^{5}$ Second, as the electoral control of politicians and the credibility of policy commitments are limited, recent research argues that the composition of the pool of politicians in terms of gender, education and occupational background matters for political outcomes. We investigate whether women elected to politics, who might have a stronger preference for public health care provision, increase public health care expenditure (as part of social expenditure). ${ }^{6}$ Third, we integrate institutional restrictions that aim at disciplining politicians budgetary discretion in general, i.e., fiscal rules and mandatory fiscal referenda. Fiscal rules increase the budgetary bargaining power of the finance minister relative to the spending ministers and create incentives for the spending ministers to be more conservative in their spending claims in order to avoid electoral punishment. Anecdotal evidence from Switzerland suggests that the budgetary process in parliament becomes more important with fiscal rules in place. This might lead to parliamentarians being more likely to be either stricter

\footnotetext{
${ }^{2}$ For instance, see Orrenius and Zavodny (2012) and Fletcher et al. (2011). For Switzerland, see Taskin and Bisig (2004) who analyze the demand for health care provision depending on socio-demographic characteristics.

${ }^{3}$ This healthy immigration effect might be reinforced if, with more immigration, natives have to work less and in physically less demanding jobs. See Giuntella and Mazzanno (2014) for a recent empirical analysis for Germany.

${ }^{4}$ See, for instance, Iversen (2001) and Potrafke (2009).

${ }^{5}$ See Schaltegger and Feld (2009) for the fiscal commons problem.

${ }^{6}$ See Besley (2005) for the importance of the selection of politicians for political outcomes. As to women in politics, Chattopadyay and Duflo (2004) study the impact of political reservation for women on local public goods provision. They find that political decision makers invest more in public infrastructure relevant to the demand of their genders. Clots-Figueras (2011) finds that female legislators in India invest more in health and early education and favor women-friendly laws. Rehavi (2007) finds that a stronger presence of women in U.S. state legislatures is related to higher state health care spending.
} 
in monitoring the governments spending behavior or more disciplined in proposing budgetary amendments. In addition, we include mandatory fiscal referenda which give the citizens more direct control over spending decisions. We test whether these institutional restrictions matter for public health care spending. Moreover, it is empirically evaluated whether political competition for upcoming elections creates incentives for incumbents to opportunistically increase public health care expenditure in order to improve their reelection chances. Several studies present evidence that supports the idea that partisan cycles in public spending exist. Reflecting the spending preferences of the electorate, left-wing politicians are assumed to care more about income distribution and to favor more expansive government spending, in particular, welfare spending. We test whether a higher share of center-left parliamentarians in parliament increases public health care expenditure. ${ }^{7}$

In a third step, we analyze whether health care policy reforms systematically impact public health care expenditure. First, we examine the impact of the Federal Health Insurance Law, which introduced mandatory basic health insurance in 1996. Mandatory health insurance was, inter alia, introduced to achieve health care cost containment. However, it has often been criticized as having the opposite effect. Second, we include the long-term care finance reform. As of 2011, a new ruling on the financing of long-term care caps the burden of care costs borne by mandatory health insurance and by persons requiring care. However, this reform, in turn, is likely to result in additional costs for the cantons. Third, as hospital costs account for a high proportion of public health care expenditure, we take the hospital finance reform, introduced in 2012, into account. The hospital finance reform, which introduced a prospective payment system (Swiss DRG), provides incentives to increase hospital cost efficiency, e.g., by the reduction of the average length of stay and, thus, could contribute to lower public health care expenditure growth.

Based on our new dataset, we exploit the enormous variation in public healthcare expenditure across cantons between 1970 and 2012. We use dynamic panel estimation methods and control for time-invariant and canton-invariant unobserved heterogeneity. We find a positive and robust elasticity of income that is close to 1 . The unemployment rate is also positively related to public health care expenditure growth. This first set of results reinforces the argument that macroeconomic conditions exert a considerable impact on public health care expenditure growth. As regards political economy aspects, it is found that public health care expenditure growth is

\footnotetext{
${ }^{7}$ For the relationship between fiscal rules and mandatory budgetary referenda and public spending and debt, see, for instance, Feld and Kirchgässner (2007), Luechinger and Schaltegger (2013) and Funk and Gathmann (2011). For electoral business cycles, see Alesina et al. (1997), Persson and Tabellini (2000) and Brender and Drazen (2005). For the partisan hypothesis, see, for instance, Hibbs (1977) and Alesina et al. (1997) and Potrafke (2009) for respective empirical studies.
} 
positively associated with the share of women elected to parliament. This result suggests that women elected to parliament systematically differ in their preferences regarding the provision of public health care services. However, institutional restrictions on the fiscal decision-making power of politicians, electoral business cycles and political partisanship do not appear to matter for public health care expenditure growth. We find no evidence for the systematic impact of the major health care policy reforms on public health care expenditure growth in our sample.

Variation in health care expenditure has been investigated in several studies. Gerdtham and Jönsson (2000) review international cross country comparisons and first panel analyses on the determinants of health care expenditure in OECD countries. Martin et al. (2011) review the more recent literature and discuss income, ageing, proximity to death, technological progress and the (de)centralized organization of health care systems in detail. According to Martin et al. (2011), the emerging picture does not show a clear pattern of results. Recently, Hartwig and Sturm (2014) investigated the empirically robust determinants of health care expenditure for a rich OECD panel data set. Confirming earlier findings, GDP growth and a variable representing Baumols cost disease theory emerge as robust determinants. As to contributions from political economy, only few studies exist. Potrafke (2010) and Herwartz and Theilen (2014) study OECD countries over the period 1971-2004 and 1970-2008, respectively. Potrafke (2010) finds evidence for electoral business cycles in public health care expenditure, whereas government ideology and coalition governments do not appear to matter. Herwartz and Theilen (2014) also find that electoral motives influence public healthcare expenditure. They document that partisan ideology impacts public health care expenditure, however, only in conjunction with a sufficiently long duration of governments in power. ${ }^{8}$ Closer to our study for Switzerland are the contributions by Crivelli et al. (2006) and Reich et al. (2012) who analyze socialized health care expenditure in Switzerland for the period 1996 to 2002 and 1997 to 2007, respectively. 9,10 While these contributions mainly focus on supply and demand-side explanations, we provide a rich empirical analysis that integrates considerations from political economy and major health

\footnotetext{
${ }^{8}$ For the U.S. states, Joshi (2015) finds no partisan effect on health care expenditure. However, an investigation of the components of health care expenditure suggests a causal effect of party affiliation on expenditures for prescription drugs.

${ }^{9}$ Socialized health care expenditure includes public health care expenditure and gross premiums of the mandatory health insurance (including individual premium subsidies). Reich et al. (2012) also add the cost-sharing of the insured to the dependent variable.

${ }^{10}$ The political scientists Vatter and Ruefli (2003) are the first to introduce political factors for Switzerland. They present a cross-cantonal regression analysis of the average of health care expenditures between 1994 and 1999 and find mixed results. Camenzind (2012) complementarily analyzes the variation of the utilization in six health care service groups for the period 20002007. He finds that a greater supply of health service providers, an older population and higher population densities are the main drivers of utilization frequency.
} 
policy reforms. Moreover, we add an important time dimension to the debate and apply dynamic panel estimation methods. We also differ with respect to results. In particular, Crivelli et al. (2006) and Reich et al. (2012) observe a negative coefficient for income elasticity. In contrast, we find a positive and robust partial correlation between per capita income and public healthcare expenditure growth.

In Section 2, we briefly depict the relevant aspects of the Swiss health care system. In Section 3 , the data is described and the empirical analysis is presented. Section 4 offers concluding remarks.

\section{Institutional background}

Switzerland has a highly decentralized health care system, in which cantons finance about two thirds of public health care expenditure and assume a key role. The cantons are responsible for the planning and provision of inpatient care (acute and long-term care), the regulation and supervision of health care matters, such as the authorization to open a medical practice or pharmacy. The cantons operate public hospitals and subsidize private hospitals, provide nursing homes and home care (Spitex). Cantons can delegate the provision of long-term care to the municipal level. In any case, cantons are responsible for licensing providers of nursing homes and home care services. The cantons are also entrusted with the implementation of the Federal Insurance Law Act (HIA) which was put in place in 1996. This law provides new regulatory powers for the federal government. One key element is the introduction of a mandatory basic health insurance (OKP). ${ }^{11}$ While ambulatory care is mainly funded by the OKP (including copayments of private households), inpatient care is funded by the OKP and the cantons. The cantons are required to draw up a list of hospitals and nursing homes (i.e., private and public institutions) that are eligible for reimbursement under the OKP. Moreover, the cantons supervise the listed hospitals and nursing homes.

Since cantons are responsible for the provision of inpatient care, we take two major recent

\footnotetext{
${ }^{11}$ The OKP offers a basic package with a uniform premium rate, which is set independently from sex and health risks of the insured person and is uniform for adults above 25 years. The mandatory basic insurance is offered by non-profit private health insurers, which are in competition at the cantonal level. Before 1996, the federal health insurance law as of 1911 was in place. The law required sickness funds who sought to apply for federal subsidies to abide by its rules such as providing a benefit package with a comprehensive coverage of health care services. The cantons were responsible to declare such statutory health insurance as mandatory or voluntary. Although this system suffered from serious drawbacks such as the funding of health insurance and solidarity concerns, every attempt of the federal government to completely overhaul the system had been rejected by the citizens until 1996 .
} 
reforms related to inpatient care into account the new arrangement of long-term care financing, which entered into force in 2011 and the new hospital finance regime put in place in 2012. The legislation for long-term care financing has led to a new arrangement in the financing of long-term care among private households, the OKP and the state. In particular, the new legislation seeks to prevent the burden of long-term care costs on the OKP from exceeding its current level of just under $21 \%$ and limits the amount paid by persons requiring long-term care to a maximum of $20 \%$ of the long-term care contribution of the OKP laid down by the federal government. The remaining long-term care costs are financed and regulated by the cantons, which have the discretion to reduce the contribution to be paid by persons requiring care. The extra burden due to the reform can be viewed as a fiscal externality that is caused by the cost caps for the mandatory health insurance and persons requiring care. The key feature of the new hospital finance regime is to move away from a cost-based reimbursement towards predetermined flatrate payments per case (diagnosis-related groups, Swiss DRG). Under a DRG-based financing, providers receive a fixed rate for each admission depending on the diagnosis. This prospective payment is known to have some shortcomings such as higher monitoring costs, revolving door effects or incentives that encourage opportunistic behavior by providers such as up-coding and cream-skimming, i.e., maximizing the number of lucrative patients and cases. However, the prospective payment system is expected to provide incentives to reduce the duration of hospital stays as hospital costs are now reimbursed on the basis of a predetermined fixed rate and not as before on a per-diem basis. Furthermore, the flat-rate-payment scheme should lead to efficiency gains in terms of specialization. ${ }^{12}$ In the short run, additional costs which arise from adjustments to the new system are borne by the cantons and the OKP. Under the reformed system of the dual financing of hospitals, the cantons and the OKP share the financing of hospitals, which make it onto a cantonal list, in a fixed proportion. In particular, this fixed proportion has to be achieved after a transition phase of five years and implies additional relative financing costs for the cantons.

\section{Empirical analysis}

\subsection{Data}

The empirical analysis is based on a novel panel data set on cantonal health care expenditures spanning the period 1970-2012 for all the 26 Swiss cantons. Cantonal health care expenditure consists of spending on hospitals, mental health facilities, nursing homes and outpatient nursing

\footnotetext{
${ }^{12}$ See Biorn et al. (2003), Böcking et al. (2008), Chern et al. (2000), Herwartz and Strumann (2014), Newhouse (1996) and Widmer (2015) for the relationship between prospective payment and hospital efficiency.
} 
care. It does not include cantonal social allowances for health such as the cantonal contribution to the individual premium reduction. In 2012, cantonal health care expenditure amounted to about one fifth of total health care expenditure in Switzerland. At the same time, cantonal health care expenditure was, on average, equal to one seventh of total cantonal expenditure. As is illustrated by Figure 1, cantonal health care expenditure varies enormously across cantons and over time. Figure A.1 in the Appendix illustrates the development of real public health care expenditure over time per canton.

The data were obtained from various sources. The information on cantonal health care expenditure was obtained from yearly publications by the Swiss Federal Finance Administration. The cantonal GDP per capita is provided by BAK Basel Economics. We obtained the unemployment rate from the Swiss State Secretariat for Economic Affairs. For some cantons and very early years, information is retrieved from the journal "Die Volkswirtschaft". The socio-demographic variables are taken from the Swiss Federal Statistical Office. Years of election, share of left-wing parties in parliament and the share of women in parliament are provided by the Swiss Federal Statistical Office. For early years, we compiled information from the Année Politique Suisse. The information on parliament size, fiscal rules and mandatory budgetary referenda is obtained from Luechinger and Schaltegger (2013), Hodler et al. (2015) and Funk and Gathmann (2011). For early years, we retrieved the information from the annual publications of the Anne Politique Suisse. The information on the health policy reforms is taken from the Federal Office of Public Health.

Compared to other countries, Switzerland has relatively low unemployment rates and a high share of foreigners which vary among cantons and across time. In 2012, the unemployment was lowest in Obwalden (0.9\%) and highest in Geneva (4.97\%). In 2012, the share of immigrants was lowest in Appenzell Inner-Rhodes (10.1\%) and highest in Geneva (39.7\%). After the introduction of women's suffrage, mostly in the early 1970s, the share of women elected to cantonal parliaments increased over time and was, on average, $24 \%$ in 2012 . While many cantons adopted mandatory fiscal referenda before our observation period starts, cantonal fiscal rules have often been introduced after the year 2000. Table A.1 in the Appendix specifies the variables and provides summary statistics.

\subsection{Methods and results}

In order to estimate which determinants affect public health care expenditure growth in the 26 Swiss cantons, we use the bias-corrected least-squares-dummy-variable estimator proposed by Bruno (2005). In contrast to the well-known estimators by Arellano and Bond (1991) and Anderson and Hsiao (1982), this estimator holds for small panels (small N) as well. The bias 
correction is performed by the bootstrapping of the standard errors. ${ }^{13}$ The standard errors are robust towards heteroscedasticity and autocorrelation. In order to avoid non-stationarity problems and as we are interested in explaining the dynamics rather than the levels of cantonal health care expenditure, we carry out all estimations in first differences of the continuous variables. All continuous variables are expressed in natural logarithms. ${ }^{14}$ The baseline estimation model is as follows:

$$
\Delta \ln \left[\text { phce }_{i}(t)\right]=\alpha+\beta \Delta \ln \left[\text { phce }_{i}(t-1)\right]+\gamma_{j} \Delta \ln \left[X(t)_{i, j}\right]+\delta_{j} Z_{i, j}(t)+\mu_{i}+\lambda(t)+\epsilon_{i}(t)
$$

whereby the dependent variable phce corresponds to real health care expenditure per capita of canton $i$ in year $t$. The matrix $X$ represents possible demand and supply-side drivers of phce such as real GDP per capita or the mortality rate. Moreover, continuous political-institutional factors such as the share of women in parliament and the share of left-wing parties in parliament belong to this group of variables. $Z$ represents a set of dummy variables which consists of political-institutional indicator variables and major Swiss health care reforms. The error term of the regression model is represented by $\epsilon$. We discuss the results along three different sets of regressions. The first set of regressions includes possible demand and supply-side drivers of phce (model I). The second set of models adds political-institutional variables (model II) and the last set introduces major health care reforms (model III). Furthermore, we vary the regression models with respect to the type of fixed-effects in order to control for unobserved heterogeneity. The first variant of regressions controls for time-invariant canton-specific effects, $\mu_{i}$ (see, for instance, Table 1, model Ia). In a second variant, we add time-specific five-year effects, $\lambda(t)$ (see e.g. Table 1, model Ib). We do not use year fixed effects as we want to explicitly include the indicator variables for the health reforms and the mortality rate as a proxy for technological progress (which is only available at the federal level).

[Table 1 about here]

The first set of results of the bias-corrected least-squares-dummy-variable (LSDV) is shown in Table 1. In all specifications, GDP per capita is statistically significant at a $1 \%$ level. We find

${ }^{13}$ The Arellano-Bond estimator is chosen to initialize the bias correction. We undertake 100 repetitions of the procedure to bootstrap the estimated standard errors. The results change neither qualitatively with a different number of repetitions nor when we choose the AndersonHsiao estimator as the initial estimator.

${ }^{14}$ Panel unit root tests indicate that the underlying panel data in growth rates are stationary. We also controlled for the fact that we use a semi-logarithmic functional form when including dummy variables. However, when we used the post estimation Stata command logdummy that accounts for the semi-logarithmic functional form, the computed coefficients of the percentage change for all dummy variables showed virtually no difference to the originally estimated dummy coefficients. Therefore, these coefficients are not additionally inserted. 
that, ceteris paribus, an increase in income growth of one percentage point is correlated with an increase in public health care expenditure growth of about 0.8 percentage points. Thus, public health care seems to be more a necessity than a luxury. ${ }^{15}$ One has to keep in mind that expenditure on nursing homes which is about one fifth of cantonal health care spending, is, however, not driven by income considerations. The coefficient for the unemployment rate is positive and robust across all specifications suggesting that the unemployed have a higher probability of illness than the employed. This first set of results suggest that the two variables characterizing the macroeconomic environment, i.e., GDP per capita and the unemployment rate, are crucial for the development of phce. The lagged dependent variable is statistically significant at the $1 \%$ level and the coefficient reveals an elasticity of about -0.24 . Demography is commonly argued to be an important determinant of health care expenditure. While the coefficient of the share of the older population is positive, it is never statistically significant. A possible explanation is that the population has been continuously ageing during the observation period in all cantons and that it is difficult to separate the effect of ageing from the five-year fixed effects. The share of the very young has a negative and statistically significant coefficient in the regression without time effects. However, the coefficient turns insignificant if five-year fixed effects are included. This confirms that the effects of the demographic structure are difficult to separate from the time fixed effects. In order to test whether the demand patterns of the foreign population in Switzerland for health care differ from the Swiss population, for example, due to different preferences or a different socio-economic background, we include the share of foreigners in our estimations. We find a statistically significant positive coefficient for the share of foreigners. This finding may be reflected in the fact that the share of migrant workers who have been occupied in physically demanding branches such as the construction and manufacturing sectors is larger than the corresponding share of Swiss workers. ${ }^{16}$ However, the decomposition of migrant workers in terms of formal education, professional training and country of origin is changing so that this relationship is likely to be different for a shorter observation

\footnotetext{
${ }^{15}$ Our findings concerning GDP per capita stand in contrast to Crivelli et al. (2006) and Reich et al. (2012) who find a negative coefficient of GDP per capita for a data set of Swiss cantons. Both studies cover a shorter period, i.e., 1996-2002 (Crivelli et al., 2006) and 1997-2007 (Reich et al., 2012) than ours, include mandatory basic health insurance contributions into the analysis and do not use dynamic panel estimators. Our findings, however, provide clear evidence for a positive relationship between income and public health care expenditure and are in line with recent empirical evidence on the relationship between income and health care expenditures. See for instance, Baltagi and Moscone (2010) for an OECD panel data analysis and Moscone and Tosetti (2010) for an analysis of the U.S. states.

${ }^{16}$ Higher demand by the immigrants might also be due to information and access problems to the health care systems which cause higher morbidity, in particular, for immigrants with low formal education, language barriers and restrained financial resources (see Taskin and Bisig 2004).
} 
period and for future analyses. We take the mortality rate to approximate advances in medical technology. According to our estimations, our proxy for advances in medical technology does not systematically influence phce. However, one has to emphasize that the mortality rate is an incomplete proxy for advances in medical technology as other factors such as the nutritional behavior and the frequency of physical exercise can influence the mortality rate. ${ }^{17}$ Furthermore, other regressors such as the five-year fixed effects or the GDP per capita might capture part of the impact of advances in medical technology. ${ }^{18}$

With respect to political economy considerations, we include a rich set of institutional and political variables. Our findings show that the size of parliament is positively related to phce. One possible explanation is that an increasing number of parliamentarians, who all seek electoral support from special interests in order to be reelected, increases the fragmentation of interests in the political decision making process. This might lead to increases in public expenditure in general and public health care expenditure in particular. However, the finding is sensitive to the inclusion of time fixed effects. Consistent with the argument that women elected to politics have a stronger preference for public health care spending (as a part of social expenditure), all regressions show a statistically significant partial correlation between the share of women in parliament and public health care expenditure growth. Neither for fiscal rules nor for mandatory fiscal referenda, do we find a disciplining effect with regard to public health care expenditure growth. Politicians, regardless of their partisan ideology, might hesitate to propose cuts in public health care expenditure as such cuts are particularly visible and affect voters perceptions (see, for instance, Pierson 1994). At the same time, citizens might regard the public provision of health care particularly important and thus they do not vote against proposed projects, which increase public health care expenditure, at the ballot box.

The introduction of mandatory health insurance does not systematically impact public health care expenditure growth. With respect to the long-term care finance reform and the hospital finance reform, we find the expected positive coefficients. However, the partial correlations are not statistically significant. The burden shifting entailed by the long-term care finance reform tends to increase cantonal health care expenditure. The new dual financing of hospitals in addition to adjustment costs of the new DRG-based remuneration scheme, which are likely to initially push up costs, are plausible explanations for the positive effect of the hospital finance reform on public health care expenditure growth. However, as the long-term care finance reform and the hospital finance reform have just been recently introduced on the federal level and as

\footnotetext{
${ }^{17}$ As alternative proxies for technological progress commonly used, we included the U.S. R\&D expenditure (as comparable Swiss data do not exist for our observation period) and a common time trend. Qualitatively, we found the same results.

${ }^{18}$ Bed density could be used as a proxy of supplier induced demand in the inpatient care sector. However, such data is available only for very recent years in the case of Swiss cantons.
} 
they cannot be clearly separated from time fixed effects, it is too soon to conclude about their impact.

[Table 2 about here]

In Table 2, we add further explanatory variables of interest. In order to estimate the impact of time-invariant socio-demographic or institutional indicator variables, i.e., Latin cantons and cantons with a university hospital, we use a random-effects generalized least squares (GLS) estimator instead of our preferred dynamic panel estimator. The variable Latin cantons should capture possibly different cultural preferences for health care between German-speaking and Latin-speaking (French and Italian-speaking) cantons. University hospitals might incur higher costs than ordinary hospitals due to the application of more advanced technologies. The GLS random-effects model suggests that Latin-speaking cantons tend to have higher public health care expenditure growth. However, once time fixed effects are included, the partial correlation between the indicator variable and public health care expenditure growth is not precisely measured. The fact that a canton operates a university hospital does not make a statistically significant difference with regard to public health care expenditure growth (see Table 2, models Ia and $\mathrm{Ib}$ ). In addition, we test the potential impact of two further prominent political-economy variables, i.e., electoral business cycles and partisan influences. In the second specification (model II) in Table 2, we, again, apply the dynamic panel estimator proposed by Bruno (2005). This specification is run separately from Table 1 due to the lack of availability of data in some cantons. While electoral budget cycles are captured by an election year dummy, partisan influence is approximated by the share of left-wing politicians in parliament as an additional measure of the spending preferences of the electorate. As left-wing politicians are assumed to care more about income distribution and to favor more expansive government spending and government intervention, a higher share of left-wing politicians is expected to increase public health care expenditure. The empirical analysis, however, suggests that both factors do not contribute to explaining the dynamics of phce and do not alter the main results. While the result for the partisan ideology is in line with the findings of Potrafke (2010) and Joshi (2015), it stands in contrast to the studies by Potrafke (2010) and Herwartz and Theilen (2014) with regard to the effect that electoral motives in election years have on public health care expenditure. This might be due to the fact that Switzerland features consensus governments. Moreover, local autonomy and strong direct democratic participation rights discipline politicians and additionally reduce the importance of electoral budgetary cycles and ideological differences. ${ }^{19}$

\footnotetext{
${ }^{19}$ In further robustness checks, we, first, tested whether our results are affected by the interplay of cantonal and local health care expenditures. Local health care spending is quantitatively much less important than cantonal spending. However, the cantons have the competences to delegate
} 


\section{Concluding remarks}

This paper has empirically studied the determinants of public health care expenditure growth. Exploiting the highly decentralized Swiss health care system, we integrate supply and demandside considerations, factors identified by the political economy literature and major health policy reforms. Based on a novel data set spanning the period 1970-2012, we find evidence that income per capita, unemployment and immigration impact the dynamics of public health care expenditure. With respect to political economy considerations, it is found that public health care expenditure growth increases with the presence of women in parliament. However, electoral business cycles, political partisanship and institutional restrictions on the discretionary budget decision making power of politicians do not appear to affect public health care expenditure significantly. The result regarding fiscal rules might imply that with fiscal rules in place and increasing public health care expenditure over time, other competing public expenditure categories are subject to more budgetary discipline. Moreover, our empirical analysis suggests that the major Swiss health care reforms have not systematically influenced public health care expenditure growth. However, the long-term care finance reform and the hospital finance reform have only recently been introduced and it is too soon to conclude about their impact.

There are several issues that would merit further research on this topic. First, one could focus on inpatient expenditure, as it constitutes the principal part of cantonal health care expenditure. The recently implemented long-term care finance reform and the hospital finance reform primarily concern the financing of hospitals. Second, Baumol's cost disease might play a role for public health care expenditure. Third, it would be interesting to investigate the determinants of public health care expenditure at the local level. Moreover, while we provide an analysis of the determinants of the variation in public health care expenditure, a comparative analysis on the corresponding consequences for the composition of total cantonal (welfare) expenditure could yield interesting insights for policy makers.

the provision of health care services to the local level. While further analyses suggest that (some) cantons shift part of the fiscal burden to the local level, our results for the determinants of cantonal health care expenditure are not affected if we take the dynamics of local healthcare expenditure into account. 


\section{References}

Alesina, A., Roubini N. and Cohen, G.D. (1997). Political Cycles and the Macroeconomy. MIT Press: Cambridge.

Anderson, T. W. and Hsiao, C. (1982). Formulation and Estimation of Dynamic Models Using Panel Data. Journal of Econometrics, 18(1): 47-82.

Arellano, M. and Bond, S. (1991). Some Tests of Specification for Panel Data: Monte Carlo Evidence and an Application to Employment Equations. Review of Economic Studies, 58(2): 227-297.

Baltagi, B. H. and Moscone, F. (2010). Health Care Expenditure and Income in the OECD Reconsidered: Evidence from Panel Data. Economic Modelling, 27(4): 804-811.

Beck, N., and Katz, J. N. (1995). What To Do (and Not To Do) with Time Series Cross-Section Data. American Political Science Review, 89(3): 634-647.

Besley, T. (2005). Political Selection. Journal of Economic Perspectives, 19(3): 43-60.

Biorn, E., Hagen, T.P., Iversen, T., Magnussen, J. (2003). The Effect of Activity-Based Financing on Hospital Efficiency: A Panel Data Analysis of DEA Efficiency Scores 19922000. Health Care Management Science, 6: 271283.

Böcking, W., Ahrens, U., Kirch, W., Milakovic, M. (2005). First Results of the Introduction of DRGs in Germany and Overview of Experience from other DRG Countries. Journal of Public Health, 13(3): 128137.

Brender, A. and Drazen A. (2005). Political Budget Cycles in New versus Established Democracies. Journal of Monetary Economics, 52: 1271-1295.

Bruno, G.S.F. (2005). Approximating the Bias of the LSDV Estimator for Dynamic Panel Data Models. Economics Letters, 87(3): 361-366.

Camenzind, P.A. (2012). Explaining Regional Variations in Healthcare Utilization between Swiss Cantons Using Panel Econometric Models. Health Services Research, 12: 62-68.

Chattopadhyay, R. and Duflo, E. (2004). Women as Policy Makers: Evidence from a Randomized Policy Experiment in India. Econometrica, 72(5): 14091443.

Chern, J.-Y., Wan, T.T.H. (2000). The Impact of the Prospective Payment System on the Technical Efficiency of Hospitals. Journal of Medical Systems, 24: 159172. 
Clots-Figueras, I. (2011). Women in Politics. Evidence from the Indian States. Journal of Public Economics, 95: 664690.

Colombier, C. (2012) Healthcare Expenditure Projections up to 2060. FFA Working Paper No. 19, Federal Department of Finance, Berne, Switzerland.

Crivelli, L., Filippini M. and Mosca, I. (2006). Federalism and Regional Healthcare Expenditure: An Empirical Analysis for the Swiss Cantons. Health Economics Letters, 15(5): 535-541.

Feld, L. and Kirchgässner, G. (2007). On the Effectiveness of Debt Brakes: The Swiss Experience, in J.E. Sturm and R. Neck (eds.). Sustainability of Public Debt, MIT Press, Cambridge (Mass.), pp. 223-255.

Fletcher, J.M.. Sindelar, J.L. and Yamaguchi S. (2011). Cumulative Effects of Job Characteristics on Health. Health Economics, 20(5): 553-570.

Funk, P. and Gathmann, C. (2011). Does Direct Democracy Reduce the Size of Government? New Evidence from Historical Data, 1890-2000. Economic Journal, 121(557): 1252-1280.

Gerdtham, U.G. and Jönsson, B. (2000). International Comparisons of Health Expenditure: Theory, Data and Econometric Analysis. In: Cuyler, A.J., Newhouse, J.P. (eds.). Handbook of Health Economics, Elsevier Science, North Holland, pp. 11-53.

Giuntella, O. and Mazzanno, F. (2014). Do Immigrants Bring Good Health? IZA Discussion Paper No. 8073. Bonn, Germany.

Hartwig, J. and Sturm, J.E. (2014). Robust Determinants of Health Care Expenditure Growth. Applied Economics, 46(36): 4455-4474.

Herwartz, H. and Theilen, B. (2014). Health Care and Ideology: A Reconsideration of Political Determinants of Public Funding in the OECD. Health Economics, 23: 225-240.

Herwartz, H. and Strumann, C. (2014). Hospital Efficiency under Prospective Reimbursement Schemes: An Empirical Assessment for the Case of Germany. European Journal of Health Economics, 15: 175-186.

Hibbs, D.A. (1977). Political Parties and Macroeconomic Policy. American Political Science Review, 71: 1467-1487.

Hodler, R., Luechinger, S. and Stutzer, A. (2015). The Effects of Voting Costs on the Democratic Process and Public Finances. American Economic Journal: Economic Policy, 7(1): 141-171. 
Iversen, T. (2001). The Dynamics of the Welfare State Expansion: Trade Openness, Deindustrialization, and Partisan Politics. In: Pierson, P. (Ed.). The New Politics of the Welfare State. Oxford University Press, New York, pp. 4579.

Joshi, N.K. (2015). Party Politics, Governors and Healthcare Expenditures. Economics and Politics, 27: 53-77.

Luechinger, S. and Schaltegger, C. (2013). Fiscal rules, Budget Deficits and Budget Projections. International Tax Public Finance 20: 785-807.

Martin, J.J., M., del Amo Gonzalez, M.P.L. and Garcia, D. C (2011). Review of the Literature on the Determinants of Healthcare Expenditure. Applied Economics, 43(1): 19-46.

Moscone, F. and Tosetti, E. (2010). Health Expenditures and Income in the United States. Health Economics, 19: 1385-1403.

Newhouse, J.P. (1996). Reimbursing Health Plans and Health Providers: Efficiency in Production versus Selection. Journal of Economic Literature, 34(3):12361263.

Orrenius, P. M. and Zavodny, M. (2009). Do Immigrants Work in Riskier Jobs? Demography, 46(3): 531-551.

Persson, T. and Tabellini, G. (2000). Political Economics. Explaining Economic Policy. MIT Press: Cambridge.

Pierson, P. (1994): Dismantling the Welfare State? Reagan, Thatcher, and the Politics of Retrenchment. Cambridge University Press.

Potrafke, N. (2009). Did Globalization Restrict Partisan Politics? An Empirical Evaluation of Social Expenditures in a Panel of OECD Countries. Public Choice, 140(12): 105124.

Potrake, N. (2010). The Growth of Public Healthcare Expenditure in OECD Countries: Do Government Ideology and Electoral Motives Matter? Journal of Health Economics, 29: 797-810.

Rehavi, M. (2007). Sex and Politics: Do Female Legislators Affect State Spending? Mimeo, University of California, Berkeley.

Reich, O., Weins, C., Schusterschnitz, C. and Thöni, M. (2012). Exploring the Disparities of Regional Healthcare Expenditures in Switzerland: Some Empirical Evidence. European Journal of Health Economics, 13: 193-202. 
Schaltegger C.A. and Feld, L.P. (2009). Do large cabinets favor large governments? Evidence on the Fiscal Commons Problem for Swiss Cantons. Journal of Public Economics, 93(1): $35-47$.

Taskin, A. and Bisig, B. (2004). Nationalität und Inanspruchnahme. In: Bisig, B. and Gutzwiller F. (eds.). Gesundheitswesen Schweiz: Gibt es Unter- oder Überversorgung? Vol. 1, Ruegger, Zürich/Chur, pp. 83-118.

Vatter, A. and Ruefli, C. (2003). Do Political Factors Matter for Healthcare Expenditure? A Comparative Study of Swiss Cantons. Journal of Public Policy, 23(3): 301-323.

Widmer, P. (2015). Does Prospective Payment Increase Hospital (In)efficiency? Evidence from the Swiss Hospital Sector. European Journal of Health Economics, 16: 407-419. 
Figures and Tables

Figure 1: Cantonal health care expenditure per capita

(in Swiss francs)

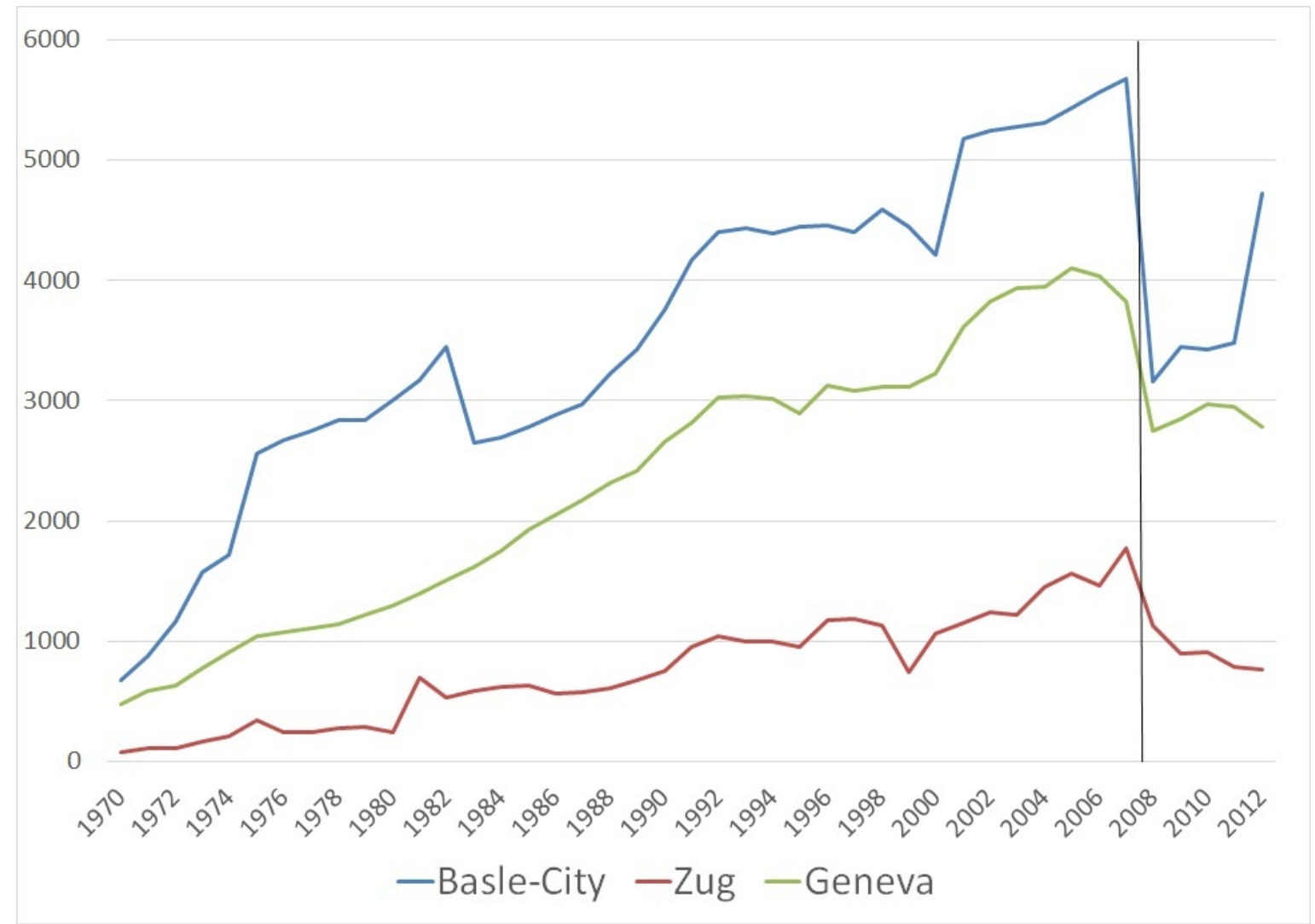

Note: Since 2008 only cantonal net contributions to public hospitals are taken into account. This revision of the government finance statistics led to a one-time downward shift in cantonal health care expenditure due to accounting reasons.

Source: Swiss Federal Finance Administration. 


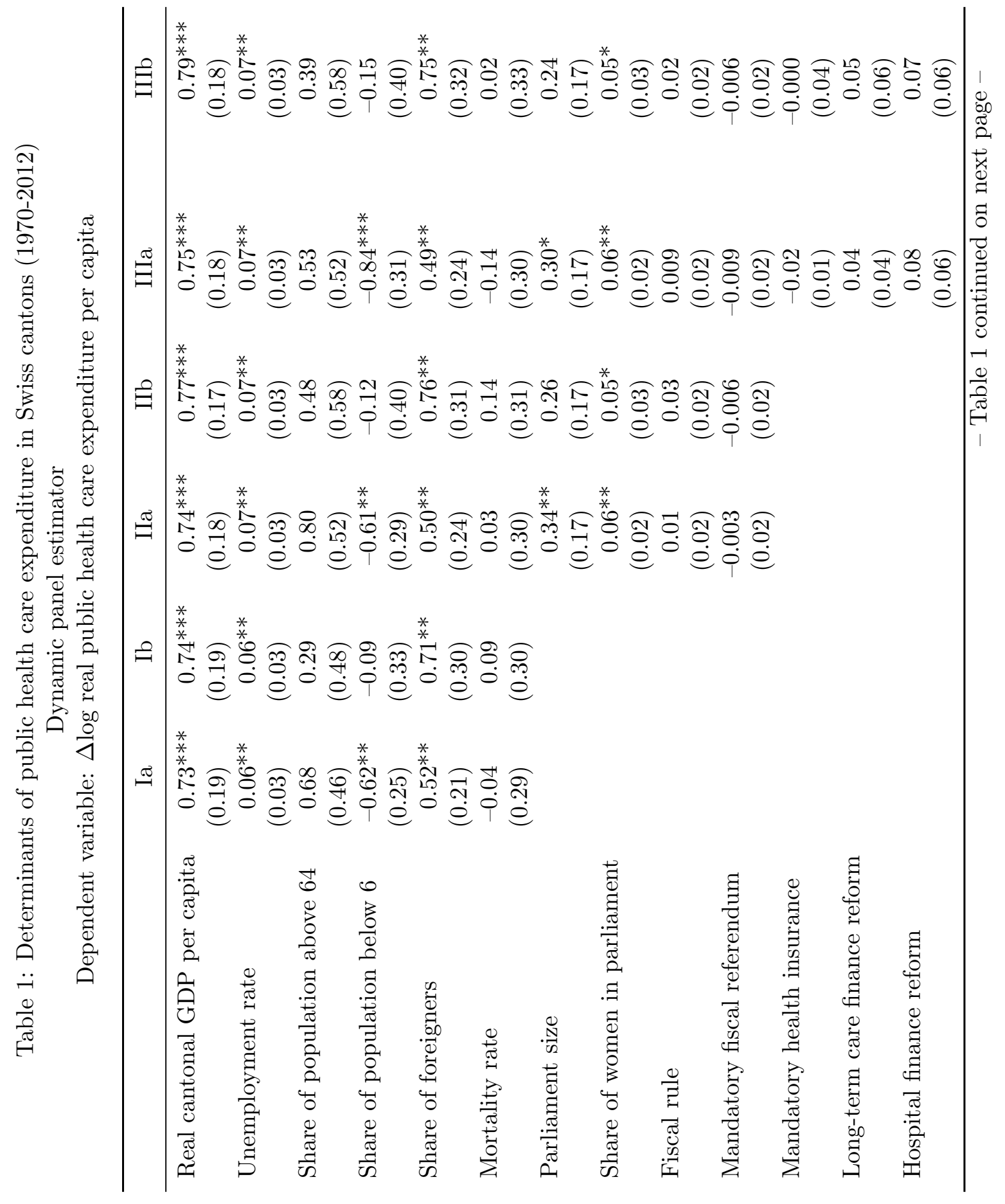




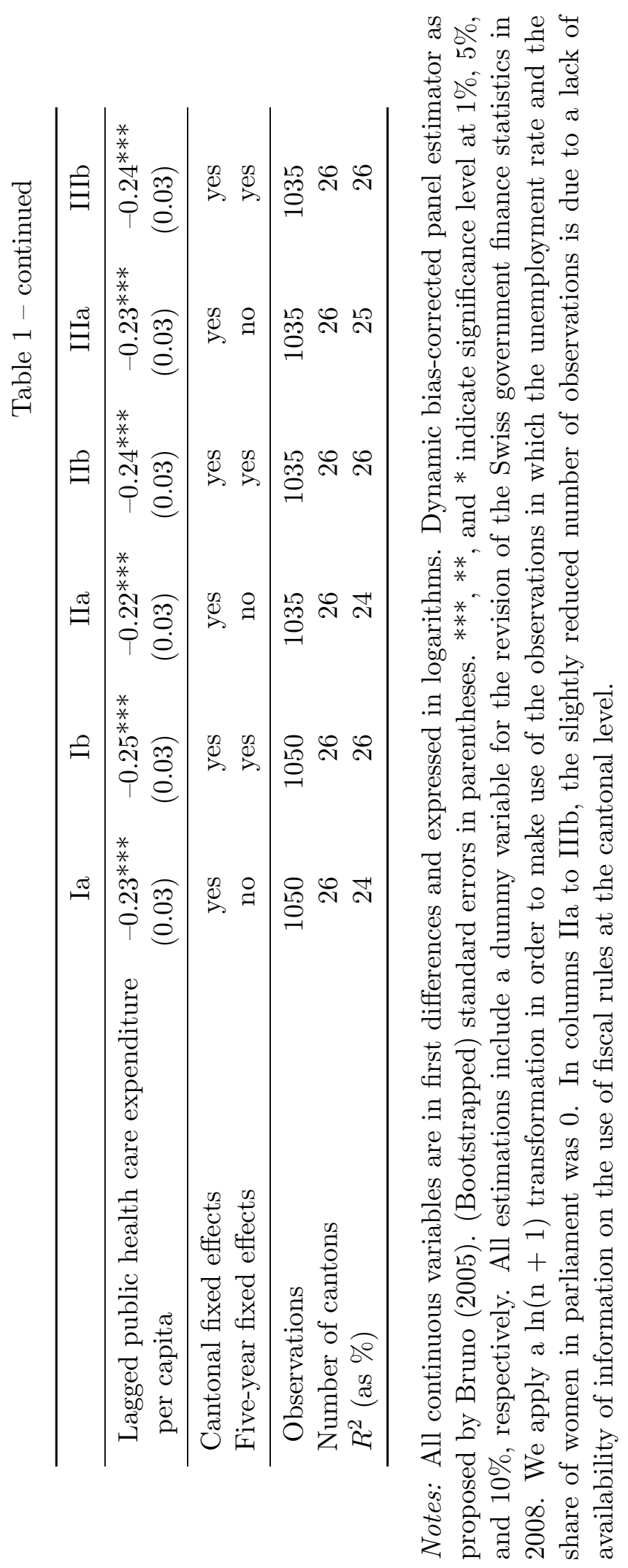


Table 2: Determinants of public health care expenditure in Swiss cantons (1970-2012) Further analyses

Dependent variable: $\Delta \log$ real public health care expenditure per capita

\begin{tabular}{lcccc}
\hline & Ia & Ib & IIa & IIb \\
\hline Real cantonal GDP per capita & $0.80^{*}$ & $0.81^{*}$ & $0.85^{* * *}$ & $0.92^{* * *}$ \\
Unemployment rate & $(0.42)$ & $(0.44)$ & $(0.20)$ & $(0.21)$ \\
& $0.07^{* *}$ & $0.07^{* *}$ & $0.07^{* *}$ & $0.07^{* *}$ \\
Share of population above 64 & $(0.03)$ & $(0.04)$ & $(0.03)$ & $(0.04)$ \\
Share of population below 6 & 0.59 & 0.39 & 0.55 & 0.47 \\
& $(0.36)$ & $(0.41)$ & $(0.58)$ & $(0.65)$ \\
Share of foreigners & $-0.56^{*}$ & -0.06 & $-0.91^{* * *}$ & -0.16 \\
Mortality rate & $(0.34)$ & $(0.46)$ & $(0.30)$ & $(0.37)$ \\
Parliament size & 0.41 & 0.56 & $0.52^{* *}$ & $0.77^{* *}$ \\
Share of women in parliament & $(0.29)$ & $(0.50)$ & $(0.22)$ & $(0.30)$ \\
Years of election & 0.07 & 0.19 & -0.06 & 0.12 \\
Share of left-wing parties in parliament & $(0.29)$ & $(0.32)$ & $(0.31)$ & $(0.34)$ \\
Fiscal rule & $0.33^{* *}$ & $0.30^{* *}$ & 0.27 & 0.18 \\
Mandatory fiscal referendum & $(0.13)$ & $(0.13)$ & $(0.17)$ & $(0.17)$ \\
Mandatory health insurance & 0.07 & 0.06 & $0.06^{* *}$ & 0.04 \\
Long-term care finance reform & $(0.06)$ & $(0.05)$ & $(0.03)$ & $(0.03)$ \\
Hospital finance reform & & & 0.003 & 0.005 \\
& & & $(0.01)$ & $(0.01)$ \\
& 0.003 & 0.005 & 0.04 & 0.03 \\
& $(0.01)$ & $(0.01)$ & $(0.02)$ & $(0.02)$ \\
& 0.006 & 0.005 & -0.001 & -0.003 \\
& $(0.01)$ & $(0.01)$ & $(0.03)$ & $(0.03)$ \\
& -0.002 & -0.002 & -0.02 & 0.001 \\
& $(0.01)$ & $(0.03)$ & $(0.02)$ & $(0.04)$ \\
& $0.04^{*}$ & $0.06^{* * *}$ & 0.03 & 0.05 \\
& $(0.02)$ & $(0.02)$ & $(0.04)$ & $(0.06)$ \\
& $0.06^{*}$ & 0.06 & 0.08 & 0.07 \\
& $(0.04)$ & $(0.04)$ & $(0.05)$ & $(0.05)$ \\
\hline
\end{tabular}

- continued on next page - 
Table 2 - continued

\begin{tabular}{lrrrr}
\hline & Ia & Ib & Ila & IIb \\
\hline Latin cantons & $0.01^{*}$ & 0.01 & & \\
& $(0.007)$ & $(0.007)$ & & \\
Cantons with university & -0.005 & -0.01 & & \\
hospital & $(0.007)$ & $(0.007)$ & & $-0.24^{* * *}$ \\
Lagged public health care & & & $(0.03)$ & $(0.03)$ \\
expenditure per capita & & - & yes & yes \\
\hline Cantonal fixed effects & - & yes & no & yes \\
Five-years fixed effects & no & 1035 & 962 & 962 \\
No. of observations & 1035 & 26 & 25 & 25 \\
No. of cantons & 26 & 21 & 26 & 27 \\
R (as\%) & 19 & & & \\
\hline
\end{tabular}

Notes: All continuous variables are in first differences and expressed in logarithms. Columns Ia and Ib: Random-effects GLS estimator and HAC standard errors. Columns IIa and IIb: Biascorrected dynamic panel estimator with bootstrapped standard errors as proposed by Bruno (2005). $* * *, * *$, and $*$ indicate significance level at $1 \%, 5 \%$, and $10 \%$, respectively. All estimations include a dummy variable for the revision of the Swiss government finance statistics in 2008. Latin cantons: Fribourg, Geneva, Jura, Neuchatel, Ticino, Vaud and Wallis. Cantons with university hospital: Basel-City, Berne, Geneva, Vaud and Zurich. Years of elections include elections for the executive or/and the legislative bodies. In columns IIa and IIb, no information on the share of left wing parties (Social Democratic Party and Green Party) is available for the canton Appenzell Inner-Rhodes and for Appenzell Outer-Rhodes until 2003. See Table 1 for further details. 


\section{Appendix}

Figure A.1: Cantonal health care expenditure per capita (1970-2012)

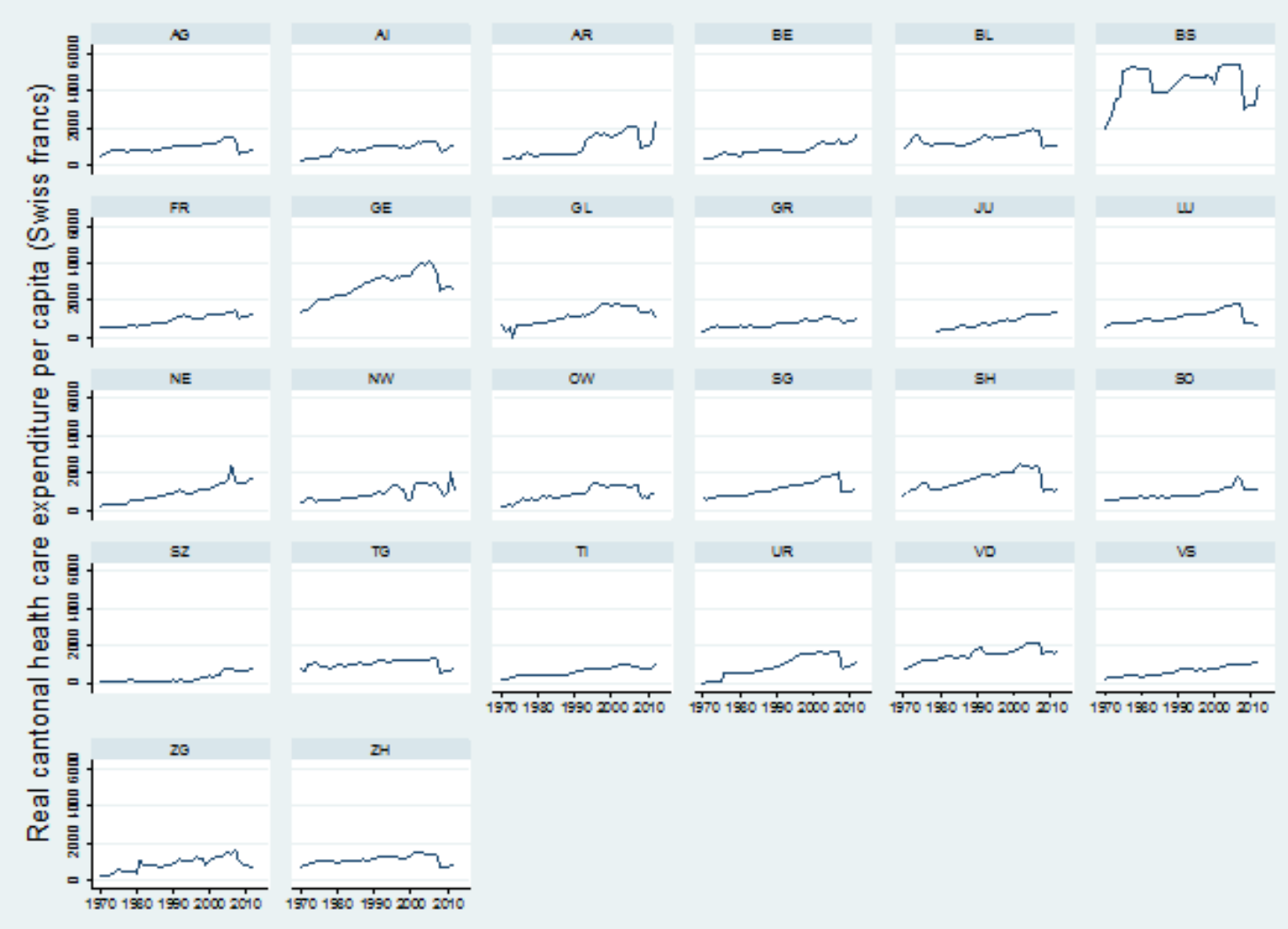

Notes: Since 2008 only cantonal net contributions to public hospitals are taken into account. This revision of the government finance statistics led to a one-time downward shift in cantonal health care expenditure due to accounting reasons. 
Table A.1: Descriptive statistics

\begin{tabular}{lccccc}
\hline & Observations & Mean & Std. dev. & Min. & Max. \\
\hline $\begin{array}{l}\text { Dependent variable } \\
\text { Real public health care expenditure }\end{array}$ & & & & & \\
$\quad$ per capita & 1109 & $1^{\prime} 185.46$ & 882.65 & 25.35 & $5^{\prime} 449.41$ \\
\hline $\begin{array}{l}\text { Independent variables } \\
\text { Real GDP per capita }\end{array}$ & 1102 & $49^{\prime}, 827.6$ & $15{ }^{\prime} 939.2$ & $22^{\prime} 048$ & $141^{\prime} 206.9$ \\
Unemployment rate & 1109 & 1.69 & 1.73 & 0 & 7.81 \\
Share of population above 64 & 1108 & 14.63 & 2.48 & 8.29 & 21.04 \\
Share of population below 6 & 1108 & 7.25 & 1.39 & 4.16 & 11.97 \\
Share of foreigners & 1084 & 16.15 & 6.91 & 4.94 & 39.66 \\
Mortality rate & 1109 & 682.94 & 151.73 & 455.8 & 987.5 \\
Parliament size & 1109 & 113 & 45.84 & 45 & 204 \\
Share of women in parliament & 1109 & 15.29 & 10.21 & 0 & 37 \\
Share left-wing parties in parliament & 1033 & 21.06 & 10.79 & 0 & 47.7 \\
\hline Independent variables (dummies) & & & & & \\
Years of election & 1109 & 0.31 & 0.46 & 0 & 1 \\
Fiscal rule & 1094 & 0.23 & 0.42 & 0 & 1 \\
Mandatory fiscal referendum & 1109 & 0.66 & 0.47 & 0 & 1 \\
Mandatory health insurance & 1109 & 0.40 & 0.49 & 0 & 1 \\
Long-term care finance reform & 1109 & 0.047 & 0.21 & 0 & 1 \\
Hospital finance reform & 1109 & 0.023 & 0.15 & 0 & 1 \\
\hline
\end{tabular}

Note: The summary statistics are shown in levels for the full sample covering the years 19702012. As the first observation for the newly founded canton Jura is 1979, we have 1109 instead of 1118 observations in our sample. For independent variables that are coded as dummies, mean values indicate the share of observations that have the specific characteristic indicated by the label of the respective variable. The values for the GDP per capita are in real Swiss francs. For the years 1970-1979, real GDP per capita is retropolated with the growth rate of the real cantonal income. From 1980 onwards, information is provided by BAK Basel Economics. The mortality rate is defined as the standardized number of deaths per 100,000 inhabitants. The reduced number of observations for the share of population above 64, the share of population below 6 , the share of foreigners and the fiscal rule are due to data availability. No information on the share of left-wing parties (Social Democratic Party and Green Party) is available for the canton Appenzell Inner-Rhodes and for Appenzell Outer-Rhodes until 2003.

Sources: Swiss Federal Finance Administration for the dependent variable. BAK Basel Economics and Swiss Federal Statistical Office for real GDP per capita. For the unemployment rate, see Swiss State Secretariat for Economic Affairs and the journal "Die Volkswirtschaft". For the socio-demographic variables, see Swiss Federal Statistical Office. For years of election, share of left-wing parties in parliament and the share of women in parliament, see Swiss Federal Statistical Office and Année Politique Suisse. Luechinger and Schaltegger (2013), Hodler et al. (2015) and Funk and Gathmann (2011) and the Année Politique Suisse for parliament size, fiscal rules and mandatory fiscal referendum. For health policy reforms, see Federal Office of Public Health. 